\title{
1 Forest conversion to conifers induces a regime shift in soil process domain affecting carbon stability
}

2 Ellen Desie ${ }^{a, 1,2}$, Karen Vancampenhout ${ }^{b, 1,2}$, Kathleen Heyens ${ }^{b}$, Jakub Hlava ${ }^{c}$, Kris Verheyen ${ }^{d}$, Bart Muys ${ }^{a, 2}$

3 a Division Forest, Nature and Landscape, KU Leuven, Celestijnenlaan 200E, Box 2411, B-3001, Leuven, Belgium

4 b Department of Earth and Environmental sciences, KU Leuven, Campus Geel, Kleinhoefstraat 4, B-2240, Geel, Belgium

5 c Department of Zoology and Fisheries, Czech University of Life Sciences Prague, Kamycka 129, Prague - Suchdol,165 00, Czech Republic

$6{ }^{d}$ Forest \& Nature Lab, Department of Environment, Ghent University, Geraardsbergsesteenweg 267, Melle-Gontrode, B-9090, Belgium 7

\section{Author contributions:}

9 B.M. designed the observational setup, K.Va. designed the geochemical and soil carbon components of the research, K. Va. and 10 K.H. designed the microbial components and B.M. and K.Ve. designed the soil fauna and ecological components of the study. E.D. 11 and J.H. collected the data and E.D. analyzed the data. All authors contributed to the interpretation of the results. E.D. and K.Va. 12 contributed equally in compiling the manuscript.

$13{ }^{1}$ contributed equally

$14 \quad 2$ corresponding author

15 Ellen Desie - ellen.desie@kuleuven.be ,+32 4786445 79;

16 Karen Vancampenhout - karen.Vancampenhout@kuleuven.be, +32 4777943 68;

17 Bart Muys - bart.muys@kuleuven.be, +32 494652895

18

19 Highlights:

20 - Forest conversion can induce a shift in soil process domain (SPD)

21 - A shift in SPD impacts different functional compartments of the soil carbon cycle

$22 \quad$ - Topsoil total carbon concentrations increase after conversion to conifers

23 - Carbon is stored in less stable pools under coniferous forest in the AI-SPD

24 - Soil carbon stability is driven by the interplay of tree species and edaphics 


\section{Abstract}

26 A substantial part of forests worldwide is located on acidic soils. Acidification processes are typically

27 characterized by non-linear responses of soils to external drivers. Acid buffer ranges and thresholds in soils

28 are widely acknowledged, yet these non-linearities are rarely incorporated into our understanding of soil

29 carbon dynamics. Here we have studied the effect of conversion of broadleaved mixed forest to Norway

30 spruce monocultures on different functional compartments of the belowground carbon cycle, i.e. litter

31 layers, soil fauna and soil micro-organisms, and have examined how in turn they affect soil biochemical

32 characteristics and ultimately, soil carbon stability. By studying this effect chain along a soil buffering

33 gradient, we were able to evaluate the relative significance of forest management versus edaphic

34 constraints on soil carbon processing. The effects of conversion are extensive and change trajectories are

35 larger for forests that shifted from one buffering domain to another upon conversion. In the latter,

36 conversion leads to a larger buildup of the litter layer, significantly stronger acidification, and a decrease in

37 microbial functional diversity and earthworm biomass in the mineral soil, mirrored by a collapse of the base

38 saturation. Although topsoil total carbon concentrations increased under spruce, this soil carbon is stored

39 in less stable carbon pools compared to broadleaved forests. These are carbon pools where carbon is not

40 occluded in aggregates or bound to soil minerals and therefore more vulnerable to environmental factors.

41 Our findings show that changes in forest composition can, depending on the initial distance from a

42 threshold in acid buffering, cascade through different compartments of the soil carbon cycle and eventually

43 alter the way carbon is stored.

\section{$44 \quad$ Key words}

45 Tree species effect, Tree species composition, Forest management, Soil acidity, Soil carbon sequestration, Regime

46 shift; Soil process domains 


\section{1. Introduction}

48 Climate-smart land management forms a principal chapter of the needed measures for decarbonization of

49 the atmosphere (Law et al., 2018; Paustian et al., 2016; Rockström et al., 2017). Carbon sequestration in

50 forest ecosystems is accordingly an ecosystem service of great importance (Lal, 2004; Minasny et al., 2017;

51 Srivastava et al., 2012). More carbon can be sequestered in the soil than in living biomass, and with longer

52 turn over times. Hence, sustainable management of forest soil carbon is of utmost importance in optimizing

53 that service (Jandl et al., 2007). As the life cycle of a managed forest typically spans decades to centuries,

54 the choice of tree species is one of the major long-term forest management decisions to be made (Seidl et

55 al., 2008; Verheyen et al., 2016). But how this decision affects carbon storage in the soil and carbon stability

56 remains little studied (Vesterdal et al., 2013). Recent efforts have been made by Angst et al. (2018) who

57 find that tree species influence soil carbon stability independently from total carbon stocks, however the

58 influence of the edaphic context remains unclear. There is accumulating evidence that edaphic constraints

59 fundamentally affect soil carbon cycling (Angst et al., 2018; Schmidt and Schmidt, 2011). Changes in soil

60 acidity, for example, may be a more important driver of soil organic matter behavior than climate, especially

61 on longer time scales (Rasmussen et al., 2018). In addition, a great portion of the world's forests are located

62 on acidic soils (Supporting information 1, Slessarev et al., 2016; FAO, 2015; IGBP-DIS, 1998). In this regard,

63 a better understanding of carbon stability in relation to tree species - site interactions seems key to optimize

64 forest management for carbon sequestration and to expand the concept of 'climate-smart' soils (sensu

65 Paustian et al. (2016)) to forests.

66 Tree species composition determines the quantity and quality of organic matter added to the litter layer

67 and the belowground compartment (Kögel-Knabner, 2017; De Schrijver et al., 2012; Reich et al., 2005).

68 Most studies that discuss tree species effects focus on litter layer characteristics and their effect on nutrient

69 cycling (Wang et al., 2016; Mueller et al., 2015; Reich et al., 2005), with little consideration for the influence

70 of the edaphic component. Some studies also mention tree species effects on total carbon stocks or carbon 
71 composition (Quideau et al., 2001; Vancampenhout et al., 2010). The chemical quality of the organic input,

72 largely determined by the forester's choice of overstory species, is however not regarded as relevant for

73 long-term stabilization of organic carbon in the soil as compared to organo-mineral interactions and

74 occlusion in aggregates (Lehmann and Kleber, 2015). Today, it is still unclear how these stabilization

75 mechanisms interact with tree species effects or vary with soil type or depth (Angst et al., 2018; Jandl et

76 al., 2007; Kögel-Knabner, 2017; Vesterdal et al., 2013). Moreover, the role of soil fauna in soil mass

77 exchange remains largely overlooked (Filser et al., 2016; Mueller et al., 2015; Prescott, 2010).

78 Current ecological thinking increasingly focusses on the non-linear behavior of natural systems (Moore et

79 al., 2009), yet successful application of such views are still scarce in soil carbon research (Vogel et al., 2018).

80 The concepts of alternative stable states, tipping points and ecosystem collapse have all been applied to

81 aboveground forest dynamics (Lindenmayer et al., 2016; Ghazoul et al., 2015; Suding et al., 2004) but

82 remain largely unexplored for belowground processes. Many studies and models still assume linear

83 relationships between carbon input and transformation to more stable forms (Jackson et al., 2017).

84 Nevertheless, Muhs (1984), Ulrich (1991) and Vitousek and Chadwick (2013) have evidenced non-linearity

85 in soil acidification processes. They introduced the concept of 'pedogenic thresholds' as "points where soil

86 properties change abruptly and/or nonlinearly with a small increment in environmental forcing" (Chadwick

87 and Chorover, 2001). The "regions between thresholds where soils change much more gradually across a

88 large range of environmental forcing" are referred to as buffer ranges or soil process domains (Vitousek

89 and Chadwick, 2013). In terms of acid buffering this is best illustrated by measured pH values, which do not

90 respond instantaneously to the input of new hydrogen ions, but reflect the buffering by several concurrent

91 or subsequent buffering mechanisms. The reactions at work in neutral and slightly acidic pH zones show

92 narrow buffer ranges, where the soil process domains quickly substitute each other. These soils are

93 therefore more susceptible to rapid change (Chadwick and Chorover, 2001). As the vast majority of the

94 world's forests have acidic soils (FAO, 2015; IGBP-DIS, 1998), most forests soils are residing in this unstable 
95 region. Nevertheless, the effects of these biogeochemical thresholds on the dominant ecological feeding

96 strategies of soil communities and the type of carbon stabilization mechanisms at work have up till now

97 been largely neglected.

98 If we accept non-linearity as a key feature of ecosystems (Moore et al., 2009), then why do we not extend

99 these insights to belowground functioning and carbon cycling? In this study we therefore aim at evaluating

100 the relative significance of tree species effects and soil process domains, sensu Vitousek \& Chadwick (2013),

101 on different functional compartments of the forest carbon cycle, i.e. the litter layer, soil fauna and soil

102 micro-organisms. We moreover aim to assess how these compartments interplay with soil biogeochemical

103 parameters and finally how they affect soil carbon storage and stability. By doing so, we want to verify if a

104 change in overstory species can induce a geochemical shift in soil process domain. If so, does this change

105 in litter quality cascade down into soil carbon dynamics? And finally, can this aboveground shift also induce

106 a regime shift in soil carbon stability? The disentangling of biotic and edaphic drivers of soil carbon dynamics

107 in forests is particularly difficult as long-term experiments are few and observational studies typically

108 struggle to differentiate between co-varying factors or legacy effects. A major reason for this confounding

109 is that mature forests where overstory species and edaphic conditions vary independently are extremely

110 rare (Augusto et al., 2002; Binkley and Giardina, 1998). In this study, we benefit from a series of

111 monocultural Norway spruce (Picea abies) stands, that were established ca. 70 years ago within a large,

112 semi-natural broadleaved forest in the Gaume (southern Belgium). In this region, natural variations in marl

113 content of the Jurassic parent material and variable addition of Quaternary eolian loess have created a

114 natural gradient of soil properties, that span the pedogenic threshold between the exchange and the

115 aluminium soil buffer domains. A twin-plot observational set-up was designed along this edaphic gradient,

116 i.e. a series of pairs of a treated (converted to spruce) and an adjacent untreated plot (unconverted to

117 spruce). The forest matrix was under the same ownership for centuries, with no previous agricultural use

118 on record (sensu Hermy 1999), largely excluding land-use legacy effects. Altogether, the natural edaphic 
119 gradient, the synchronized forest conversion, and the paired sampling between converted and

120 unconverted plots along the gradient form a unique design allowing the assessment of conversion effect in 121 relation to Ulrich's and Chadwick's soil process domains. 


\section{2. Material and Methods}

\subsection{Study region}

124 The study area is part of a $200 \mathrm{~km}^{2}$ forested area in southern Belgium, the Gaume region (centre $49^{\circ} 37^{\prime} \mathrm{N}$, $1255^{\circ} 33^{\prime} \mathrm{E}$ ) (Supporting information 2). This region contains one of the largest complexes of ancient forest in

126 Belgium. We define ancient as being continuously forested since land use records began in Belgium in 1777

127 (Hermy et al., 1999). The deciduous forest matrix is uneven-aged, mixed and mostly dominated by Quercus

128 robur L., Fagus sylvatica L. and Carpinus betulus L. Between 1960 and 1980 several patches, size 2-15ha,

129 were clear-cut and replanted with Norway spruce monocultures. This particular land use history allows

130 evaluating conversion effects while largely excluding other land use legacies, as the whole semi-natural

131 forest matrix was managed as coppice with standards under the same ownership for centuries, and the

132 spruce conversion happened a few decades ago in a relatively short lapse of time. The Gaume region is

133 characterized by the intertwining of two geological formations (the Arlon and Luxembourg formation),

134 which are both Jurassic calcareous sandstone (grès calcaire) with varying marl content (Supporting 135 information 2). The landscape is part of a cuesta between the Ardennes and the Paris basin. A thin and 136 discontinuous Quaternary aeolian loess deposition occurred on North-facing slopes. This range in parent

137 materials has translated into a natural variation in soil properties in terms of intrinsic buffering capacity (in

138 casu $\mathrm{CEC}_{\text {clay }}$ ) and in reserve of weatherable bases. As a result, a range of soil $\mathrm{pH}$ values can be encountered,

139 that spans the pedogenic threshold between the exchange and the aluminium soil buffer domains

140 (Verstraeten et al., 2018). Soil texture varies from sand to loam and profiles can be classified as Luvisols,

141 Alisols and Cambisols (IUSS Working Group WRB, 2015). The topsoils are characterized by relatively poor

142 soil fertility as a consequence of the sandy substrate, a lack of free carbonates and a slow natural

143 weathering to replenish base saturation (Bouezmarni et al., 2009). 
144 Along the gradient in soil fertility a twin-plot design was established. For each Norway spruce plot (10m x $14510 \mathrm{~m}$ ) situated in an island of coniferous forest amidst the mixed deciduous matrix, an adjacent mixed 146 deciduous plot $(10 \mathrm{~m} \times 10 \mathrm{~m})$ was established, with the plot centers about $30 \mathrm{~m}$ from the edge between both 147 patches and about $60 \mathrm{~m}$ from each other, as a compromise between edaphic comparability and minimizing 148 mutual tree influence (Fig. 1). In addition, all spruce plots have similar stand age, and have similar elevation 149 and slope or orientation as the neighboring deciduous plot as to assure comparability in soil type, forest 150 history and original tree species composition.

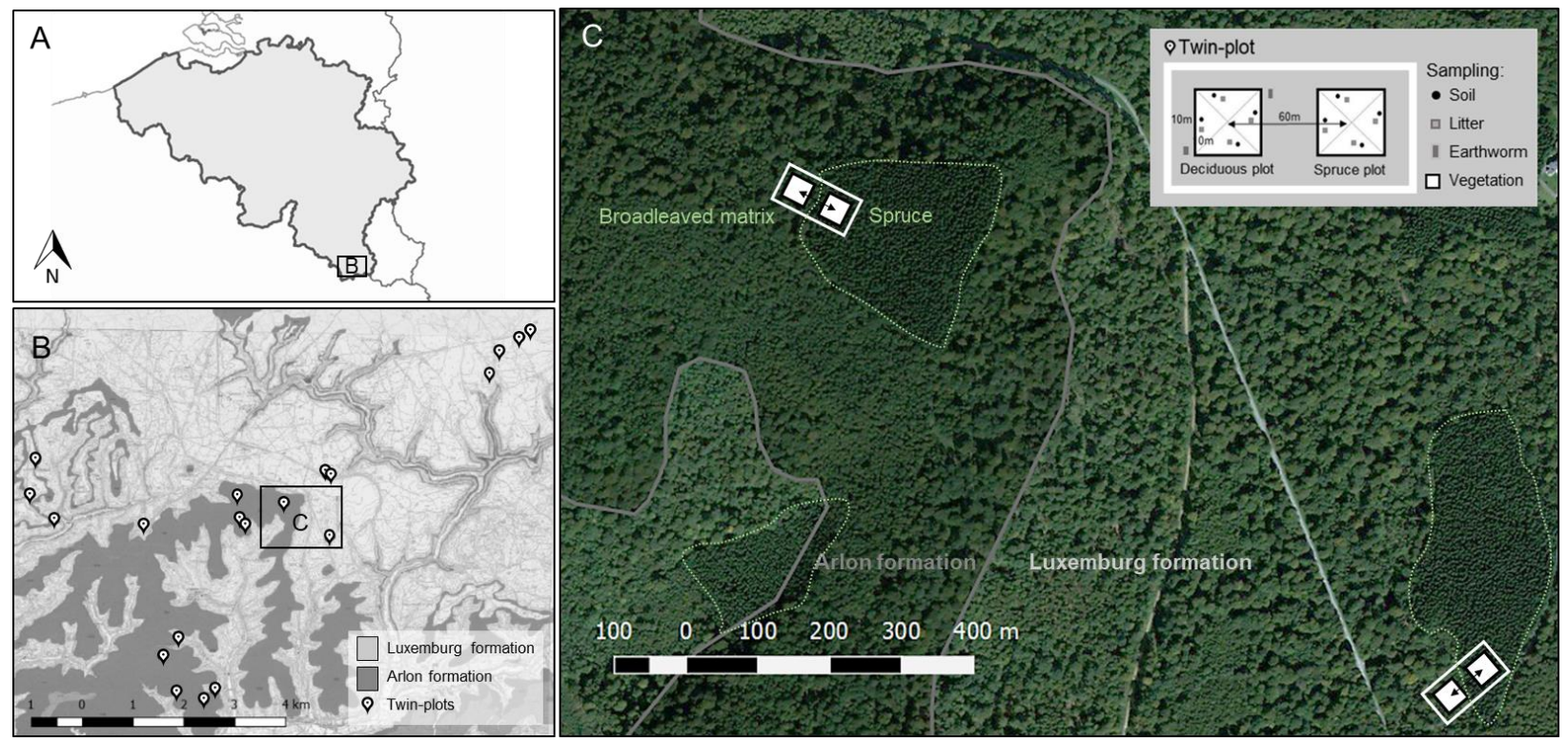

Figure 1: A) Geographical situation of study region in Belgium, B) Twin-plots (pins) on geological map of the study region with the 153 Luxemburg formation (light grey) and the Arlon formation (dark grey), C) Cut-out showing two twin-plots located in the two 154 different geological formations, and detailed sampling positions used per plot.

\subsection{Data collection}

156 Data was collected during subsequent field campaigns in 2009 (earthworms and litter layers), 2013

157 (biogeochemistry and microbiota) and 2015 (soil carbon). Earthworm communities were sampled in opposite corners of each plot (Figure 1 - top right) (Verstraeten et al., 2018) by subsequent sampling and

159 hand sorting the forest floor, mustard extraction on the same surface of the mineral soil (surface of $0.5 \mathrm{~m}^{2}$, 
earthworms were collected directly after coming to the surface) and by hand sorting a soil core taken within

161 the mustard treated area $\left(0.1 \mathrm{~m}^{2}, 20 \mathrm{~cm}\right.$ deep) (De Wandeler et al., 2018; Valckx et al., 2011). All earthworms

162 were killed and preserved in 95\% ethanol and afterwards fixed in 5\% formalin solution. They were identified

163 at species level following Sims and Gerard (1999). Earthworm biomass was expressed as $\mathrm{g} / \mathrm{m}^{2}$ ethanol

164 preserved mass. The forest floor was collected in a separate square of $20 \times 20 \mathrm{~cm}^{2}$, separated in fresh litter

165 layer $(\mathrm{L})$, fermentation layer $(\mathrm{F})$ and humus layer $(\mathrm{H})$. The litter samples were dried at $70^{\circ} \mathrm{C}$ until constant

166 mass and weighed. The total forest floor mass equals the sum of the three separate layers. Vegetation and

167 humus types were described according to Braun-Blanquet (1964) and Zanella et al. (2014) respectively.

168 Composite soil samples, consisting of 4 sampling points randomly chosen in each quadrant of the plot, were

169 collected at three depth intervals $(0-5 \mathrm{~cm}, 10-20 \mathrm{~cm}, 25-35 \mathrm{~cm})$ using a soil corer. Soil samples were dried at

$17040^{\circ} \mathrm{C}$ until constant mass. Soil texture was measured by laser granulometry (Malvern Mastersizer S) after

171 pretreatment for removal of organic material. Soil pH-KCl (extraction in $1 \mathrm{M} \mathrm{KCL}, 1: 5$ suspension, ion specific

172 electrode: ISRIC and FAO 2002) was measured for all depths. Cation exchange capacity (CEC) and base

173 saturation (BS) were determined by extraction with cobalt hexamine (Ciesielski et al., 1997) and pH-water

174 was measured ( $1: 5$ suspension, ion specific electrode: ISRIC) for the topsoil $(0-5 \mathrm{~cm})$ and subsoil $(25-30 \mathrm{~cm})$

175 layer. The soil for microbial analysis was sampled according to Muys et al. (2013) and microbial functional

176 diversity was determined using Biolog EcoPlates after preparation of the soil samples (Gaublomme et al.,

177 2006). Due to the time consuming carbon fractionation procedure the carbon research was executed on a

178 subset of 10 twin-plots that spans the variation within the original dataset (Supporting information 2). The

179 chemical carbon fractionation was executed based on the Zimmerman protocol (Zimmermann et al., 2007).

180 All soil samples were divided into 4 separate fractions: sand and stable aggregates $(S+A)$, silt and clay $(s+c)$,

181 particulate organic matter (POM) and dissolved organic carbon (DOC). For each of those fractions, in

182 addition to the total soil sample, carbon contents were measured by dry combustion $\left(900^{\circ} \mathrm{C}\right.$ Shimadzu 
$1835050 \mathrm{~A}$ element analyzer). The division of carbon over stable ( $\mathrm{S}+\mathrm{A}$ and $\mathrm{s}+\mathrm{c}$ ) and labile (POM and DOC) carbon

184 pools serves as a proxy for carbon stability (Zimmermann et al., 2007).

\section{$185 \quad 2.3$ Data analysis}

186 To evaluate the edaphic context of the study site, a K-means clustering analysis was executed on the

187 deciduous plots based on variables indicative of soil buffering capacity and dominating soil process domain

188 (Chadwick and Chorover (2001) and Vitousek and Chadwick (2013)): i.e. soil texture (sand content, clay

189 content) and CEC, BS, exchangeable Al concentration and exchangeable calcium concentration measured

190 at 25-30 cm. This analysis (Supporting information 4) separates the deciduous plots into two distinct

191 clusters, with variable values that correspond to respectively the exchange buffer domain and the

192 aluminium buffer domain (hereafter exchange domain and Al domain; according to Chadwick and Chorover

193 (2001) and Vitousek and Chadwick (2013)).

194 To evaluate the effect of conversion on soil variables, including variables indicating for the edaphic gradient 195 in the study site, a principal components analysis was executed including both deciduous and spruce plots

196 (Fig. 2). On top of the variables sand content, subsoil CEC and subsoil exchangeable Al, also topsoil pH,

197 topsoil base saturation, topsoil exchangeable Al, earthworm biomass and litter and subsoil functional 198 diversity (MBD litter and MBD sub) were included. The factor map of the variables was plotted rescaled but 199 with true inter-distances and contributions behind the factor map of the individuals. In the factor map, the 200 deciduous and spruce plot of every twin-plot are connected with a line to show the their change trajectory 201 along the variable factor map (Fig. 2). The visualized difference in conversion effect between soil process 202 domains (based on previously identified clusters, vide supra) was then further tested by means of mixed 203 models with site of the twin-plot as a random factor. The results of a post-hoc multiple comparison test are 204 indicated in the boxplots. All statistical analyses were performed with R 3.3.2. 


\section{3. Results}

\subsection{Conversion effects on soil process domains}

207 We first examined how natural variations in the Jurassic and Quaternary parent material of the study site

208 have determined soil acidity and site conditions independently from conversion to spruce. Hence, we

209 allocated the deciduous plots to the exchange domain or the Al domain based on $\mathrm{K}$-means clustering on

210 variables indicative of soil buffering capacity and ions on the exchange complex in the deciduous plots (see

2112.3 and Supporting information 4). Deciduous forest plots allocated to the exchange domain typically have

212 a base saturation above the 30\% threshold (Chadwick and Chorover, 2001) and range up to $80 \%$, with a

213 mean of $62 \%$. Aluminum concentrations are below $0.11 \mathrm{~g} \mathrm{Al}^{3+} / \mathrm{kg}$ soil whereas deciduous forest plots in the

214 Al domain have base saturation values always below $30 \%$ and aluminum concentrations up to $0.21 \mathrm{~g} \mathrm{Al}{ }^{3+} / \mathrm{kg}$

215 soil. Next, we evaluated the impact of overstory conversion relative to the initial soil process domain by a

216 principal components analysis on deciduous and spruce plots (Fig. 2; plots belonging to the same twin are

217 connected by a line). Principal component (PC) 1 explained $46.16 \%$ of the variation within the dataset and

218 PC 2 explained 14.81\% respectively. This analysis illustrates the large natural range in site conditions under

219 a deciduous overstory (Fig. 2: circles) while the converted plots (Fig. 2: triangles) show a more narrow

220 range. All converted plots show a shift to the right, which corresponds to a decrease in topsoil pH and BS

221 and an increase in topsoil $\mathrm{Al}^{3+}$, and can be allocated to the Al domain. Moreover, conversions of deciduous

222 plots initially in the exchange domain (Fig. 2: light blue circles) to spruce are characterized by larger

223 trajectories along PC1 compared to conversions of twins that were already within the aluminium domain

224 prior to conversion, which corresponds to a larger change in belowground ecosystem functioning. 


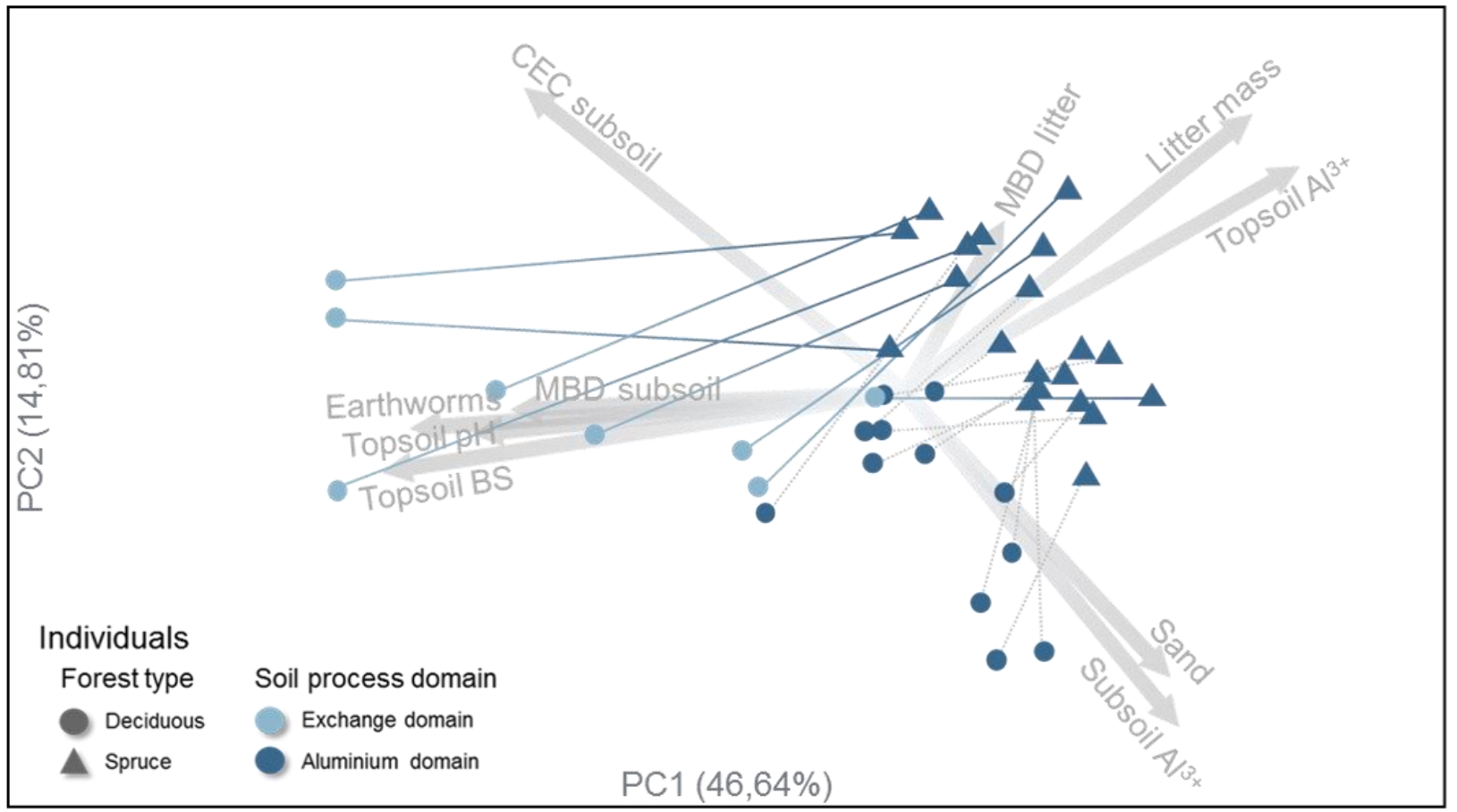

226 Figure 2: Principal components analysis on deciduous forest plots and plots converted to spruce. Deciduous plots are indicated by

227 dots whereas spruce monocultures by triangles. Plots belonging to the same twin are linked by a line. A distinction is made (based

228 on a $\mathrm{K}$ means cluster analysis (Supporting information 4)) between deciduous plots located in the exchange domain before

229 conversion (light blue) and plots that were already in the Al domain prior to conversion (dark blue). The first PC corresponds mostly

230 with the overstory conversion effects whereas the soil process domain of the deciduous plots is a function of both first and second

231 PC. Deciduous forest plots initially located in the exchange domain show larger trajectories along the first axis upon conversion

232 than deciduous forest plots already in the Al domain. Abbreviations in the figure: microbial diversity (MBD) and cation exchange capacity $(C E C)$. $(N=40)$. 


\subsection{Conversion effects on litter layers, decomposer communities and soil biogeochemistry}

235 Overall, we found significant changes in soil biotic communities and soil biogeochemistry after overstory 236 conversion. Accumulation of organic matter in the litter layer is double under spruce compared to mixed

237 broadleaved forest (Fig. 3: A and B). Additionally, our results indicate that initial soil process domain and 238 conversion both affect the earthworm biomass, which is significantly reduced from the exchange domain 239 to the Al domain, and upon conversion (Fig. 3: C). Although the biomass of burrowing earthworms is 240 drastically lower in the Al domain (with average values of $2 \mathrm{~g} / \mathrm{m}^{2}$ in contrast to $40 \mathrm{~g} / \mathrm{m}^{2}$ in the exchange 241 domain), some rather acid tolerant burrowing earthworm species, e.g. Aporrectodea caliginosa and

242 Lumbricus rubellus (Muys and Granval, 1997), are still present in the Al domain under deciduous vegetation

243 (Supporting information 6), while after conversion to spruce, only strict acid tolerant litter dwelling 244 earthworm species without burrowing capacities survive (Supporting information 6). Functional microbial 245 catabolic diversity is well distributed over the litter-soil horizons in deciduous plots in the exchange domain, 246 and somewhat shifted towards the upper compartments in deciduous plots in the Al domain (Fig. 3: D).

247 Conversion induces a sharp discontinuity in the microbial catabolic functioning between litter and soil (Fig.

248 3: D). In terms of soil biogeochemistry, soil acidity and soil base saturation (BS) increase significantly from 249 the exchange domain to the Al domain and even more with conversion to spruce (Fig. 3: E, G and H). The 250 drop in $\mathrm{pH}$ and $\mathrm{BS}$ is larger for sites where conversion induces a shift from one soil process domain to 251 another. For these sites pH drops from 5.1 to 4.1 and BS shifts from $62 \%$ to $16 \%$ in the topsoil and $48 \%$ to $2528 \%$ in the subsoil. Moreover, the higher clay content of these sites (Verstraeten et al., 2018) leads to a 253 larger potential to build up toxic aluminium cations on the exchange complex (Fig. 3: F). 

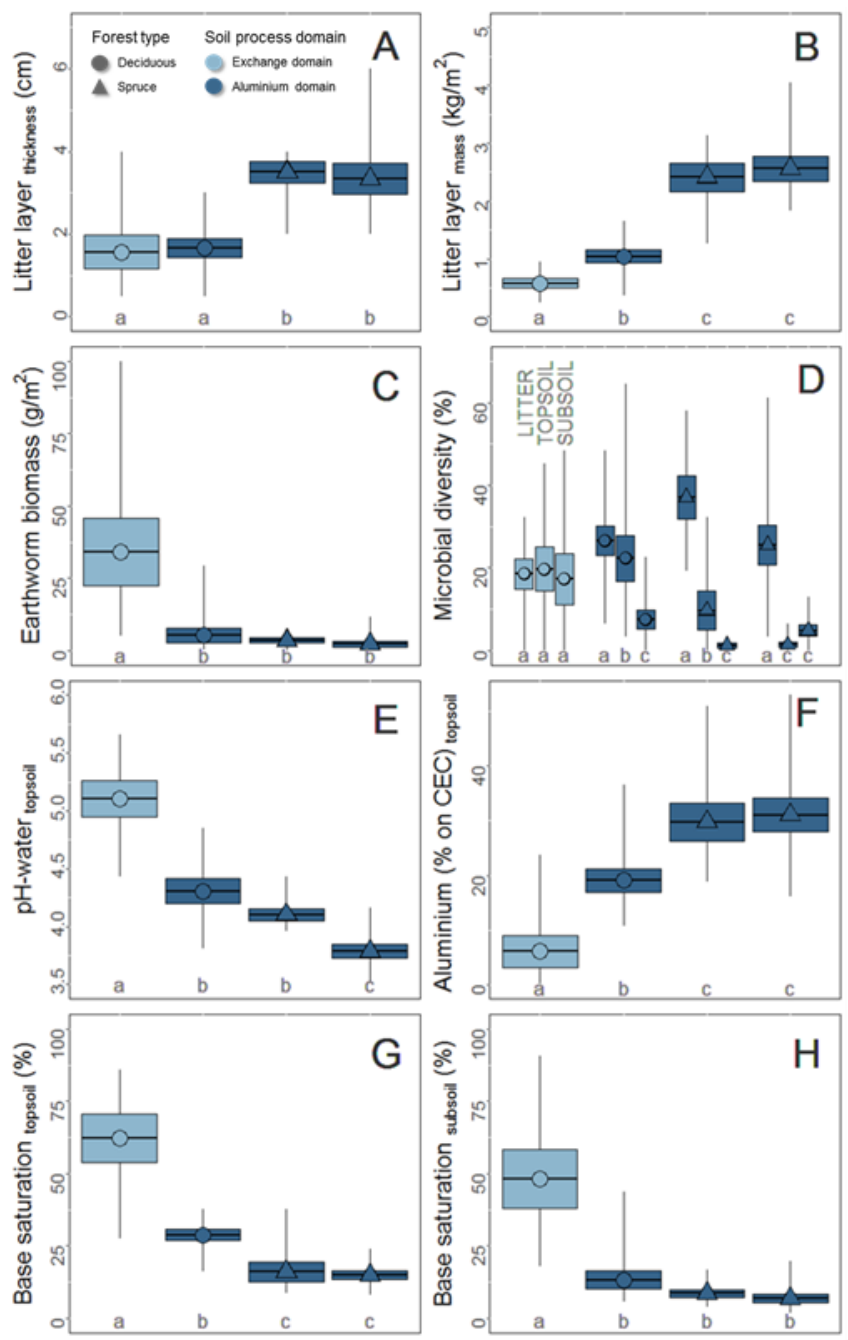

255 Figure 3: Values (range, standard error and mean) per forest type and per initial soil process domain for litter layer thickness (A),

256 litter layer mass (B), earthworm biomass (C), functional microbial diversity (D), topsoil pH (E) topsoil aluminium on the CEC (F),

257 topsoil and subsoil base saturation ( $G$ and H). A distinction is made between deciduous plots initially in the exchange domain (light

258 blue) or in the Al domain (dark blue). Results of a post hoc multiple comparison test $(\alpha<0.05)$ are indicated below the boxes:

259 different letters indicate a significant difference between the mean of two boxes. $(N=40)$. 


\subsection{Conversion effects on soil carbon sequestration}

261 Mineral topsoil total carbon concentrations increase from 3\% to 4\% with a conversion to spruce regardless

262 the initial soil process domain (Fig. 4: A). However under spruce less carbon is stored in the sand and stable

263 aggregates $(\mathrm{S}+\mathrm{A})$ fraction and more in the labile fraction particulate organic matter (POM) and stable

264 fraction silt and clay fraction $(s+c)$ as defined by Zimmermann et al. (2007). The relative storage of carbon

265 over such stable and labile pools is lower under spruce than under deciduous forest (Fig. 4: E). This effect

266 becomes particularly distinct when data are split into soil process domains: in the Al domain a smaller

267 proportion of topsoil carbon is stored in stable aggregates $(S+A)$, whereas a larger fraction of topsoil carbon

268 is stored as more labile particulate organic matter (POM) (Fig. 4: D and F).
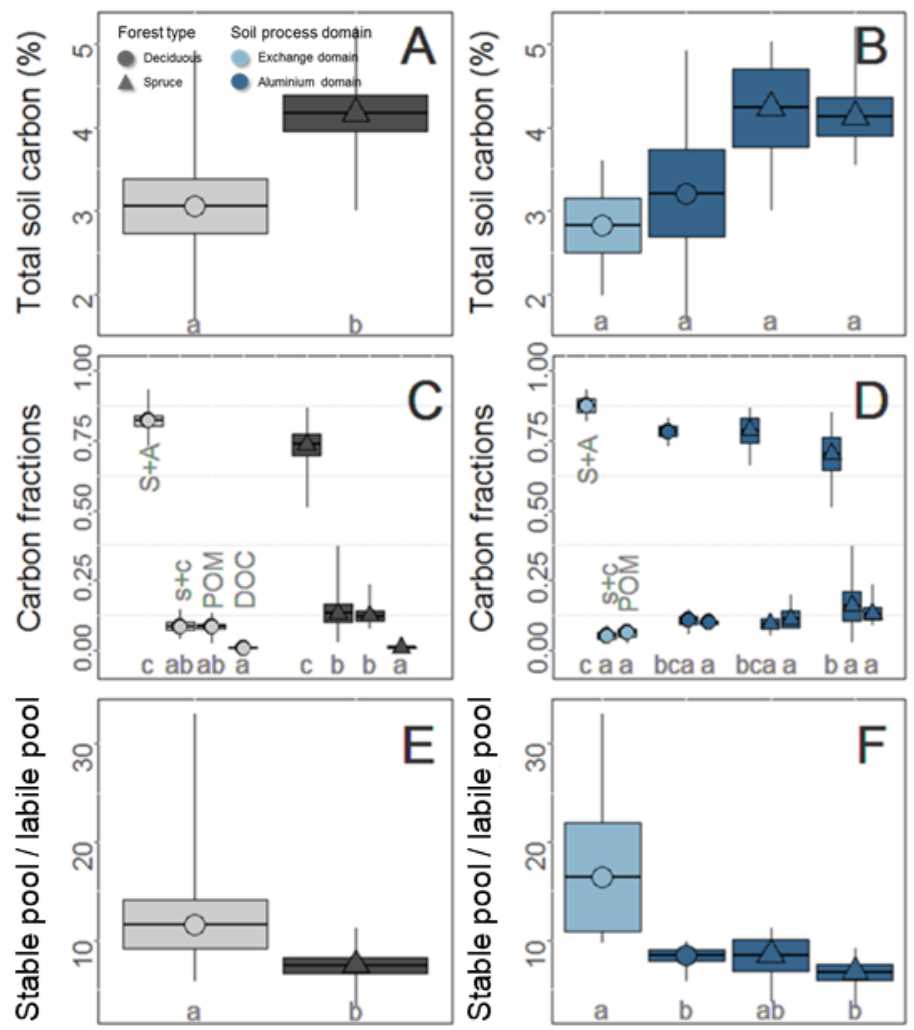

270

Figure 4: Values (range, standard error and mean) for total carbon stocks (A and B), carbon fractions (sand and stable aggregates

$271-S+A$, silt and clay $-s+c$, particulate organic matter - POM and dissolved organic carbon $-D O C)(C$ and $D)$ and the division of 
273 spruce) and per initial soil process domain (right graphs: light blue for the exchange domain and dark blue for the Al domain). In

274 the analyses per soil process domain carbon stored in the DOC fraction showed no variation and was therefore not included in the

275 graph. Results of a post hoc multipe comparison test $(\alpha<0.1)$ are indicated under the boxplot. $(N=20)$. 


\section{Discussion}

\subsection{Can a change in litter quality induce a shift in soil process domain?}

278 Comparison of the deciduous plots along the edaphic gradient showed contrasting values in terms of soil 279 acidity and soil base saturation that support the idea that our study site is indeed a system residing either 280 closely above or below a pedogenic threshold in soil process domain. Therefore, our twin setup of conifer

281 conversion along a gradient is particularly suitable for evaluating whether management-induced non282 linearities in acid buffering can also affect the broader dynamics of belowground functioning. Our results 283 confirm the adverse impact of Norway spruce effects on soil quality described in literature: accumulation 284 of organic material in the litter layer is higher, earthworm biomass is reduced, soil acidity and aluminium 285 saturation are higher and base saturation lower under spruce compared to mixed deciduous forest 286 (Vesterdal et al. 2008; Reich et al. 2005; Hagen-Thorn et al. 2004; Augusto et al. 2002; Binkley \& Valentine 287 1991). Additionally, our results show that the initial soil process domain determines the trajectory upon 288 conversion, with conversion effects being more pronounced in deciduous plots originally located in the 289 exchange domain. This seems counterintuitive, but is in line with Verstraeten et al. (2018) who found for 290 the same sites that the most dramatic impact of conversion on soil geochemistry occurs in the richest plots,

291 i.e. the plots that were still in the exchange domain prior to conversion to conifers. Indeed, after conversion, 292 all plots resided in the more acid Al domain, which substantiates the hypothesis that for the edaphic 293 situation of the Gaume forest, an increment in acid load induced by the change in litter quality is enough

294 to deplete the remaining base cations left on the exchange complex and topple the soil system from the 295 exchange domain into the Al domain.

\subsection{How far does a change in litter quality cascades down into soil carbon dynamics?}

297 The adverse effects of low quality spruce litter on the belowground ecosystem are no novelty (Augusto et 298 al. 2002; Reich et al. 2005; Vesterdal et al. 2008), yet the distinct behavior of the conversion trajectories 
299 per initial soil process domain is striking. Although the thickness of the litter layer seems to reveal little

300 difference between process domains, a shift in ecological functionality becomes evident when studying the

301 soil organisms. As a consequence of the decrease in earthworm biomass, the incorporation of organic

302 material into the mineral soil is hampered, leading to a vertical decoupling of material flows between the

303 litter layer and the soil, and between soil horizons (Muys et al., 1992). Besides the redistribution of nutrients

304 and carbon in the mineral soil by bioturbation, earthworms also improve litter palatability for micro-

305 organisms by fragmenting larger organic matter particles and by their gut passage (Brown et al., 2000). The

306 functional change in soil fauna therefore co-occurs with a fundamental change in microbial communities.

307 There is an abrupt decoupling of microbial catabolic diversity between the soil and the litter layer, with

308 most functionality now in the forest floor layers where organic substrates are more plentiful. Catabolic

309 diversity in the soil itself becomes particularly low, illustrating the harsh soil conditions in the Al domain.

310 Hence, our findings are in line with an observed increase in the activity of bacterial stress genes as a reaction

311 to soil acidity reported in literature (Song et al., 2017). The implications of this fundamental change in

312 decomposer functionality moreover becomes obvious in the soils' biogeochemistry: the increased

313 production of acids as intermediate decomposition products in accumulating litter layers is known to affect

314 the soil pH (de Vries et al., 1995), yet our data show that a shift in carbon cycles from the soil to the litter

315 layer not only increases acid load but also triggers a collapse of base cation concentrations in the subsoil as

316 decomposer activity becomes more superficial.

317 The described change in belowground communities and mass exchange further affects the way carbon is

318 stored in the mineral soil. Similar to the observed accumulation of non-stabilized organic material in the

319 forest floor layer, mineral topsoil total carbon concentrations increase with a conversion to spruce

320 regardless the initial soil process domain. However, not all carbon stored in the topsoil is equally well

321 protected from microbial decay. Occlusion in aggregates ( $\mathrm{S}+\mathrm{A}$ carbon fraction) and interaction between

322 organic molecules and soil minerals ( $s+c$ carbon fraction) make organic components inaccessible to 
323 microbes as compared to non-protected carbon present as particles (POM carbon fraction) or in solution

324 (DOC carbon fraction) (Zimmermann et al., 2007) where it is much more susceptible to disturbances and

325 decomposition. Our results indicate that with a shift in soil process domain from the exchange domain to

326 the Al domain, also topsoil carbon processing is altered. Although more carbon is stored, it accumulates

327 partly in more labile fractions, mostly as POM, and thus the stability of this carbon storage decreases. The

328 here mentioned POM fraction is based on a chemical fractionation described by Zimmermann et al. (2007)

329 and corresponds with the "large" POM fraction reported by Angst et al. (2018), who also define it as a labile

330 SOC fraction, contrary to their "small" POM fraction. Hence, even on the relatively short time span of a few

331 decades, there is a trade-off between topsoil carbon storage and carbon stability between soil process

332 domains. With progressing time, this trade-off is expected to increase. Our results support the idea of

333 Prescott (2010) and Liang et al. (2017): rather than slowing down the carbon cycle by planting species with

334 more recalcitrant litter, it is a more sustainable climate mitigation strategy to divert litter into

335 decomposition pathways with more active entombing of soil carbon in the stable fraction by soil fauna or

336 anabolic processes. Moreover, low quality litter implies a potential threat to tree health and productivity,

337 as our data evidences important knock-on effects in terms of acidity, availability of nutrients and 338 accumulation of toxic exchangeable aluminium.

339 Some studies have suggested a trade-off between forest floor layers, topsoil and subsoil carbon 340 sequestration (Vesterdal et al., 2013) and have emphasized the importance of deep soil carbon (Li et al.,

341 2012; Rumpel and Kögel-Knabner, 2011). As our main focus was soil biota and the link with soil edaphics

342 and carbon processing, we limited the study to the first $35 \mathrm{~cm}$. Also in that regard, we do not research the

343 impact of root litter input on carbon sequestration as well as root exudates on soil acidity. Moreover,

344 turnover time generally increases with depth and the spruce stands are relatively young (ca. 70 yrs),

345 therefore we focused on the more rapidly evolving leaf litter pathway. Nevertheless, further research of

346 tree species effects on deep soil carbon is necessary as the contribution of subsoils to the total soil carbon 
347 budget cannot be neglected (Rumpel and Kögel-Knabner, 2011). The effect of habitat continuity, or the lack

348 of it due to a clear cut and forest conversion, on carbon dynamics also needs further attention (Leuschner

349 et al., 2013; Nitsch et al., 2018).

\subsection{Can tree species conversion induce a regime shift?}

351 An essential question towards management is now whether the observed non-linearity in our dataset is

352 merely a threshold, or whether it represents a regime shift between stable states, sensu Scheffer et al.

353 (2001). In case of a regime shift, simply changing overstory species in the next rotation back to deciduous

354 will be insufficient to shift the degraded soil back to a more favorable process domain, and hence more

355 effort will be required for a complete restoration. Although it was not possible to study reverse trajectories

356 in our in-field setup, several observations indicate that hysteresis may be considerable which is one of the

357 key characteristics of regime shifts in ecosystems. First, the cascade of effects from decomposer

358 communities to the soils' biogeochemistry and carbon cycling, described above, strongly suggests the

359 existence of a substrate-soil-biota positive feedback loop, complicating the reversibility of the process. In

360 addition, the slow recolonization speed of earthworms (Valckx et al., 2010) impedes fast return of soil

361 faunal communities to the previous state. Recent publications moreover suggest that regaining lost

362 functional pathways in soil microbial communities may also be slower than previously assumed (Morriën

363 et al., 2017), and it is evident from our results that edaphic properties and faunal activity are closely

364 mirrored in the microbial functional diversity. Managing soil fauna may therefore be necessary upon

365 restoration, and may be the most promising avenue to steer soil microbial cycles in support of carbon

366 sequestration and other forest ecosystem services (Cotrufo et al., 2013; Singh et al., 2010). Second, the

367 strong retention of aluminium on the soils' exchange complex in comparison to base cations is a potential

368 cause of hysteresis, thus making restoration of $\mathrm{pH}$ and base saturation more difficult after crossing a

369 pedogenic threshold, and this effect becomes more pronounced with increasing CEC (Chadwick and 370 Chorover, 2001). 
371 In addition, although it seems counterintuitive that deciduous plots with higher initial buffering capacity

372 experience more extreme adverse effects from overstory conversion, such longer trajectories are typical

373 for ecosystems that undergo a regime shift (Fig. 1 and Fig. 5: trajectory A->B compared to trajectory A'-

$374>B^{\prime}$ ). Along with the above described positive feedback mechanisms it is a strong argument for the existence

375 of acidity-mediated stable states in the forest's belowground ecosystem.

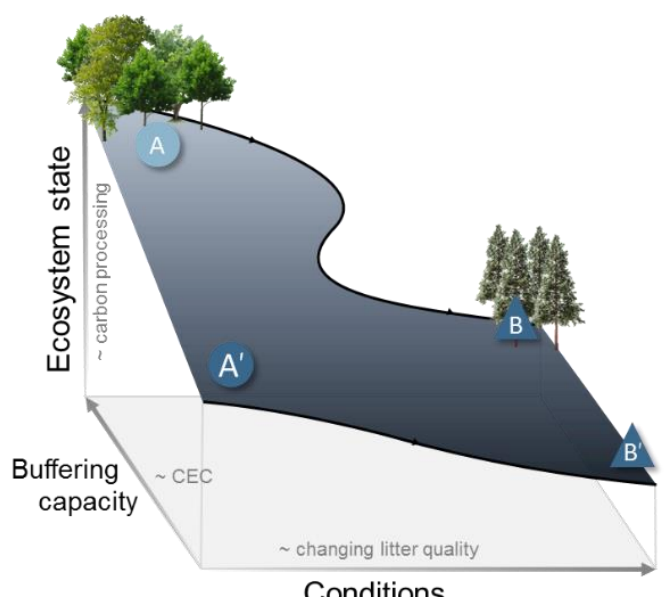

377 Figure 5: Conceptual representation of pedogenic regime shifts in temperate forests following tree species conversion from 378 broadleaved ( $A$ and $\left.A^{\prime}\right)$ to spruce ( $B$ and $\left.B^{\prime}\right)$. The belowground ecosystem state is affected by a change in litter quality (conditions) and this response is modulated by the CEC (acid buffering capacity) of the site. A site initially located in the exchange domain (A) undergoes a regime shift when litter quality is changed by overstory conversion, whereas sites that are already in the Al domain $\left(A^{\prime}\right)$ under deciduous vegetation (circles) have a smaller more gradual response to the change in litter quality (triangle).

In general, the restoration of all natural systems showing stable states may require large efforts and involve 383 high costs for society, or at worst may even be unfeasible (Steffen et al., 2018). For this reason, avoiding regime shifts is key in the management of natural systems (Ghazoul et al., 2015; Lindenmayer et al., 2016; Scheffer et al., 2001), certainly in a context of climate change mitigation. In forestry and agricultural systems where humans as ecosystem engineers directly interfere in the species composition for their own benefit, i.e. the selection of a certain crop or tree species and the choice for a mixture or monoculture, caution is always necessary. However, this also reveals a great management opportunity: near pedogenic thresholds 
389 the impact of management is largest, so by identifying sites in that condition, conservation measures can

390 be targeted to where they will be most effective. This also emphasizes that soil boundary conditions can

391 no longer be overlooked when studying tree species effects and in the process of making forest

392 management decisions, especially with carbon sequestration and climate-smart soil management in mind.

\section{5. Conclusions}

394 Our study on tree species conversion from broadleaved forest to spruce monocultures along a natural 395 edaphic gradient shows the strong effect of overstory species and its leaf litter quality on belowground 396 forest ecosystem processes, but also emphasizes the existence and prominent role of a pedogenic 397 threshold in acid buffering modulating the change trajectory upon this conversion. This means that 398 depending on the initial distance from a pedogenic threshold, effects of tree species conversion on the soil 399 functioning and the way soil carbon is stored may either translate in small changes or in a true regime shift.

400 Sites belonging to the exchange buffer domain but closely located to the threshold with the aluminium

401 buffer domain show a more extreme response in terms of change in acidity, base saturation, earthworm 402 biomass and carbon stability compared to forests already residing in the Al buffer domain. From a practical 403 forest management perspective, we showed that slowing down decomposition by the promotion of tree 404 species with more recalcitrant litter is not a good strategy to optimize carbon sequestration. Although 405 recalcitrant litter input leads to a higher carbon concentration in forest floor and topsoil, this carbon is 406 stored in less stable pools and thus more exposed to disturbances. As pedogenic thresholds occur in many

407 forms and many places around the world, taking into account such non-linearities in the belowground 408 ecosystem when considering forest management decisions is crucial.

\section{Acknowledgements}

410 We thank the municipal councils of Virton and Etalle and ir. B. Van Doren of the Cantonnement de Virton 411 of the Walloon Department of Nature and Forest for permission to access the forest and for providing 
412 information on the local forest management. We would like to acknowledge the support of Dr. Gorik

413 Verstraeten, Jeroen Buelens, Dries Martens, Michaël Van Raemdonck and Olaf Brock in the data collection

414 and the help of Kim Vekemans, Dr. Tim De Clercq and Dr. Bart Kerré during the laboratory analysis. Also we

415 would like to thank Dr. Ana Rita Sousa-Silva and Dr. Koenraad Van Meerbeek for their feedback on the

416 manuscript. E.D. holds a SB-doctoral fellowship of the Research Foundation Flanders (FWO). 


\section{References}

418

419

420

421

422

423

424

425

426

427

428

429

430

431

432

433

434

435

436

437

438

439

440

441

Angst, G., Mueller, K.E., Eissenstat, D.M., Trumbore, S., Freeman, K.H., Hobbie, S.E., Chorover, J., Oleksyn, J., Reich, P.B., Mueller, C.W., 2018. Soil organic carbon stability in forests: distinct effects of tree species identity and traits. Global Change Biology gcb.14548. doi:10.1111/gcb.14548

Augusto, L., Ranger, J., Binkley, D., Rothe, A., 2002. Impact of several common tree species of European temperate forests on soil fertility. Annals of Forest Science 59, 233-253. doi:10.1051/forest:2002020

Binkley, D., Giardina, C., 1998. Why do Tree Species Affect Soils? The Warp and Woof of Tree-soil Interactions. Biogeochemistry 42, 89-106. doi:10.1023/A:1005948126251

Binkley, D., Valentine, D., 1991. Fifty-year biogeochemical effects of green ash, white pine, and Norway spruce in a replicated experiment. Forest Ecology and Management 40, 13-25. doi:10.1016/0378-1127(91)90088-D

Bouezmarni, M., Denne, P., Debbaut, V., 2009. Carte hydrologique Meix-devant-Virton Virton. Campus d'Arlon, Belgique.

Braun-Blanquet, J., 1964. Pflanzensoziologie. Springer Vienna, Vienna. doi:10.1007/978-3-7091-8110-2

Brown, G.G., Barois, I., Lavelle, P., 2000. Regulation of soil organic matter dynamics and microbial activity in the drilosphere and the role of interactions with other edaphic functional domains. European Journal of Soil Biology 36, 177-198. doi:https://doi.org/10.1016/S1164-5563(00)01062-1

Chadwick, O.A., Chorover, J., 2001. The chemistry of pedogenic thresholds. Geoderma 100, 321-353. doi:10.1016/S00167061(01)00027-1

Ciesielski, H., Sterckeman, T., Santerne, M., Willery, J.P., 1997. Determination of cation exchange capacity and exchangeable cations in soils by means of cobalt hexamine trichloride. Effects of experimental conditions. Agronomie 17, 1-7. doi:10.1051/agro:19970101

Cotrufo, M.F., Wallenstein, M.D., Boot, C.M., Denef, K., Paul, E., 2013. The Microbial Efficiency-Matrix Stabilization (MEMS) framework integrates plant litter decomposition with soil organic matter stabilization: do labile plant inputs form stable soil organic matter? Global Change Biology 19, 988-995. doi:10.1111/gcb.12113

De Schrijver, A., De Frenne, P., Staelens, J., Verstraeten, G., Muys, B., Vesterdal, L., Wuyts, K., Van Nevel, L., Schelfhout, S., Verheyen, K., 2012. Tree species traits cause divergence in soil acidification during four decades of postagricultural forest 
443

de Vries, W., Kros, J., van der Salm, C., 1995. Modelling the impact of acid deposition and nutrient cycling on forest soils. Ecological Modelling 79, 231-254. doi:10.1016/0304-3800(93)E0121-I

De Wandeler, H., Bruelheide, H., Dawud, S.M., Dănilă, G., Domisch, T., Finér, L., Hermy, M., Jaroszewicz, B., Joly, F.-X., Müller, S., Ratcliffe, S., Raulund-Rasmussen, K., Rota, E., Van Meerbeek, K., Vesterdal, L., Muys, B., 2018. Tree identity rather than tree diversity drives earthworm communities in European forests. Pedobiologia 67, 16-25. doi:10.1016/j.pedobi.2018.01.003

FAO, 2015. Global Forest Resources Assesment. Rome.

Filser, J., Faber, J.H., Tiunov, A. V., Brussaard, L., Frouz, J., De Deyn, G., Uvarov, A. V., Berg, M.P., Lavelle, P., Loreau, M., Wall, D.H., Querner, P., Eijsackers, H., Jiménez, J.J., 2016. Soil fauna: key to new carbon models. Soil 2, 565-582. doi:10.5194/soil-2-565-2016

Gaublomme, E., De Vos, B., Cools, N., 2006. An indicator for Microbial Biodiversity in Forest Soils. Brussel.

Ghazoul, J., Burivalova, Z., Garcia-Ulloa, J., King, L.A., 2015. Conceptualizing Forest Degradation. Trends in Ecology \& Evolution 30, 622-632. doi:10.1016/j.tree.2015.08.001

Hagen-Thorn, A., Callesen, I., Armolaitis, K., Nihlgård, B., 2004. The impact of six European tree species on the chemistry of mineral topsoil in forest plantations on former agricultural land. Forest Ecology and Management 195, 373-384. doi:10.1016/j.foreco.2004.02.036

Hermy, M., Honnay, O., Firbank, L., Grashof-Bokdam, C., Lawesson, J.E., 1999. An ecological comparison between ancient and other forest plant species of Europe, and the implications for forest conservation. Biological Conservation 91, 9-22. doi:10.1016/S0006-3207(99)00045-2

IGBP-DIS, 1998. SoilData(V.0) A program for creating global soil-property databases. France.

IUSS Working Group WRB, 2015. World Reference Base for Soil Resources 2014, update 2015 International soil classification system for naming soils and creating legends for soil maps. Rome.

Jackson, R.B., Lajtha, K., Crow, S.E., Hugelius, G., Kramer, M.G., Piñeiro, G., 2017. The Ecology of Soil Carbon: Pools, Vulnerabilities, and Biotic and Abiotic Controls. Annual Review of Ecology, Evolution, and Systematics 48, 419-445. 
Jandl, R., Lindner, M., Vesterdal, L., Bauwens, B., Baritz, R., Hagedorn, F., Johnson, D.W., Minkkinen, K., Byrne, K.A., 2007. How strongly can forest management influence soil carbon sequestration? Geoderma 137, 253-268.

471

Kögel-Knabner, I., 2017. The macromolecular organic composition of plant and microbial residues as inputs to soil organic matter: Fourteen years on. Soil Biology and Biochemistry 105, A3-A8. doi:10.1016/J.SOILBIO.2016.08.011 in carbon dense temperate forests. Proceedings of the National Academy of Sciences of the United States of America 115, ancient beech forests in the German Pleistocene: The role of tree species and forest history. doi:10.1016/j.foreco.2013.08.043 analysis. New Phytologist 195, 172-181. doi:10.1111/j.1469-8137.2012.04150.x

Liang, C., Schimel, J.P., Jastrow, J.D., 2017. The importance of anabolism in microbial control over soil carbon storage. Nature Microbiology 2, 17105. doi:10.1038/nmicrobiol.2017.105 the Environment 14, 561-568. doi:10.1002/fee.1434 Field, D.J., Gimona, A., Hedley, C.B., Hong, S.Y., Mandal, B., Marchant, B.P., Martin, M., McConkey, B.G., Mulder, V.L., O’Rourke, S., Richer-de-Forges, A.C., Odeh, I., Padarian, J., Paustian, K., Pan, G., Poggio, L., Savin, I., Stolbovoy, V., Stockmann, U., Sulaeman, Y., Tsui, C.-C., Vågen, T.-G., van Wesemael, B., Winowiecki, L., 2017. Soil carbon 4 per mille. Geoderma 292, 59-86. doi:10.1016/J.GEODERMA.2017.01.002 
Moore, S.A., Wallington, T.J., Hobbs, R.J., Ehrlich, P.R., Holling, A.C.S., Levin, S., Lindenmayer, D., Pahl-Wostl, C., Possingham, H., Turner, M.G., Westoby, M., Moore, S.A., Wallington, T.J., Hobbs, Á.R.J., Ehrlich, P.R., Holling, C.S., Levin, S., Lindenmayer, D., Pahl-Wostl, C., Possingham, H., Turner, M.G., Westoby, M., 2009. Diversity in Current Ecological Thinking: Implications for Environmental Management. Environmental Management 43, 17-27. doi:10.1007/s00267-008-9187-2

Morriën, E., Hannula, S.E., Snoek, L.B., Helmsing, N.R., Zweers, H., De Hollander, M., Soto, R.L., Bouffaud, M.-L., Buée, M., Dimmers, W., Duyts, H., Geisen, S., 2017. Soil networks become more connected and take up more carbon as nature restoration progresses. Nature Communications 8. doi:10.1038/ncomms14349

Mueller, K.E., Hobbie, S.E., Chorover, J., Reich, P.B., Eisenhauer, N., Castellano, M.J., Chadwick, O.A., Dobies, T., Hale, C.M., Jagodziński, A.M., Kałucka, I., Kieliszewska-Rokicka, B., Modrzyński, J., Rożen, A., Skorupski, M., Sobczyk, Ł., Stasińska, M., Trocha, L.K., Weiner, J., Wierzbicka, A., Oleksyn, J., 2015. Effects of litter traits, soil biota, and soil chemistry on soil carbon stocks at a common garden with 14 tree species. Biogeochemistry 123, 313-327. doi:10.1007/s10533-015-0083-6

Muhs, D.R., 1984. Intrinsic thresholds in soil systems. Physical Geography 5, 99-110.

Muys, B., Granval, P., 1997. Earthworms as bio-indicators of forest site quality. Soil Biology and Biochemistry 29, $323-328$. doi:10.1016/S0038-0717(96)00047-8

Muys, B., Lust, N., 1993. Synecologische evaluatie van regenwormactiviteit en strooiselafbraak in de bossen van het vlaamse gewest als bijdrage tot een duurzaam bosbeheer Phd, 335p.

Muys, B., Lust, N., Granval, P., 1992. Effects of grassland afforestation with different tree species on earthworm communities, litter decomposition and nutrient status. Soil Biology and Biochemistry 24, 1459-1466. doi:10.1016/0038-0717(92)90133-I

Muys, B., Malchair, S., Carnol, M., De Wandeler, H., 2013. Micro-organism sampling.

Nitsch, P., Kaupenjohann, M., Wulf, M., 2018. Forest continuity, soil depth and tree species are important parameters for SOC stocks in an old forest (Templiner Buchheide, northeast Germany). Geoderma 310, 65-76. doi:10.1016/J.GEODERMA.2017.08.041

Paustian, K., Lehmann, J., Ogle, S., Reay, D., Philip Robertson, G., 2016. Climate-smart soils 532, 49-57. doi:10.1038/nature17174

Prescott, C.E., 2010. Litter decomposition: what controls it and how can we alter it to sequester more carbon in forest soils? Biogeochemistry 101, 133-149. doi:10.1007/s10533-010-9439-0 
517

Quideau, S.A., Chadwick, O.A., Benesi, A., Graham, R.C., Anderson, M.A., 2001. A direct link between forest vegetation type and soil organic matter composition, Geoderma.

Rasmussen, C., Heckman, K., Wieder, W.R., Keiluweit, M., Lawrence, C.R., Berhe, A.A., Blankinship, J.C., Crow, S.E., Druhan, J.L., Hicks Pries, C.E., Marin-Spiotta, E., Plante, A.F., Schädel, C., Schimel, J.P., Sierra, C.A., Thompson, A., Wagai, R., 2018. Beyond clay: towards an improved set of variables for predicting soil organic matter content. Biogeochemistry 137, 297306. doi:10.1007/s10533-018-0424-3

Reich, P.B., Oleksyn, J., Modrzynski, J., Mrozinski, P., Hobbie, S.E., Eissenstat, D.M., Chorover, J., Chadwick, O.A., Hale, C.M., Tjoelker, M.G., 2005. Linking litter calcium, earthworms and soil properties: a common garden test with 14 tree species. Ecology Letters 8, 811-818.

Reich, P.B., Oleksyn, J., Modrzynski, J., Mrozinski, P., Hobbie, S.E., Eissenstat, D.M., Chorover, J., Chadwick, O.A., Hale, C.M., Tjoelker, M.G., 2005. Linking litter calcium, earthworms and soil properties: a common garden test with 14 tree species. Ecology Letters 8, 811-818.

Rockström, J., Gaffney, O., Rogelj, J., Meinshausen, M., Nakicenovic, N., Schellnhuber, H.J., 2017. A roadmap for rapid decarbonization. Science (New York, N.Y.) 355, 1269-1271. doi:10.1126/science.aah3443

Rumpel, C., Kögel-Knabner, I., 2011. Deep soil organic matter-a key but poorly understood component of terrestrial C cycle. Plant and Soil 338, 143-158. doi:10.1007/s11104-010-0391-5

Scheffer, M., Carpenter, S., Foley, J.A., Folke, C., Walker, B., 2001. Catastrophic shifts in ecosystems. Nature 413, 591-596. doi:10.1038/35098000

Schmidt, S., Schmidt, M., 2011. Persistence of soil organic matter as an ecosystem property. Nature 478, 49-56.

Seidl, R., Rammer, W., Lasch, P., Badeck, F.-W., Lexer, M.J., 2008. Does Conversion of Even-Aged, Secondary Coniferous Forests Affect Carbon Sequestration? A Simulation Study under Changing Environmental Conditions. Silva Fennica 42, 369-386.

Sims, R.W., Gerard, B.M., 1999. Keys and Notes for the Identification and Study of the Species. Schrewsbury: Field Studies Council.

Singh, B.K., Bardgett, R.D., Smith, P., Reay, D.S., 2010. Microorganisms and climate change: terrestrial feedbacks and mitigation options. Nature Reviews Microbiology 8, 779-790. doi:10.1038/nrmicro2439 
542

543

544

545

546

547

548

549

550

551

552

553

554

555

556

557

558

559

560

561

562

563

564

565

566

567

Slessarev, E.W., Lin, Y., Bingham, N.L., Johnson, J.E., Dai, Y., Schimel, J.P., Chadwick, O.A., 2016. Water balance creates a threshold in soil pH at the global scale. Nature Publishing Group 540. doi:10.1038/nature20139

Song, H.-K., Song, W., Kim, M., Tripathi, B.M., Kim, H., Jablonski, P., Adams, J.M., 2017. Bacterial strategies along nutrient and time gradients, revealed by metagenomic analysis of laboratory microcosms. FEMS Microbiology Ecology 93. doi:10.1093/femsec/fix114

Srivastava, P., Kumar, A., Behera, S.K., Sharma, Y.K., Singh, N., 2012. Soil carbon sequestration: an innovative strategy for reducing atmospheric carbon dioxide concentration. Biodiversity and Conservation 21, 1343-1358. doi:10.1007/s10531012-0229-y

Steffen, W., Rockström, J., Richardson, K., Lenton, T.M., Folke, C., Liverman, D., Summerhayes, C.P., Barnosky, A.D., Cornell, S.E., Crucifix, M., Donges, J.F., Fetzer, I., Lade, S.J., Scheffer, M., Winkelmann, R., Schellnhuber, H.J., 2018. Trajectories of the Earth System in the Anthropocene. Proceedings of the National Academy of Sciences of the United States of America. doi:10.1073/pnas.1810141115

Suding, K.N., Gross, K.L., Houseman, G.R., 2004. Alternative states and positive feedbacks in restoration ecology. Trends in Ecology \& Evolution 19, 46-53. doi:10.1016/j.tree.2003.10.005

Ulrich, B., 1991. An Ecosystem Approach to Soil Acidification, in: Soil Acidity. Springer Berlin Heidelberg, Berlin, Heidelberg, pp. 28-79. doi:10.1007/978-3-642-74442-6_3

Valckx, J., Govers, G., Hermy, M., Muys, B., 2011. Optimizing Earthworm Sampling in Ecosystems. Springer, Berlin, Heidelberg, pp. 19-38. doi:10.1007/978-3-642-14636-7_2

Valckx, J., Pennings, A., Leroy, T., El Berckmans, D., Govers, G., Hermy, M., Muys, B., 2010. Automated observation and analysis of earthworm surface behaviour under experimental habitat quality and availability conditions. Pedobiologia 53, 259-263. doi:10.1016/j.pedobi.2009.12.005

Vancampenhout, K., De Vos, B., Wouters, K., Van Calster, H., Swennen, R., Buurman, P., Deckers, J., 2010. Determinants of soil organic matter chemistry in maritime temperate forest ecosystems. Soil Biology and Biochemistry 42, $220-233$. doi:10.1016/j.soilbio.2009.10.020

Verheyen, K., Vanhellemont, M., Auge, H., Baeten, L., Baraloto, C., Barsoum, N., Bilodeau-Gauthier, S., Bruelheide, H., Castagneyrol, B., Godbold, D., Haase, J., Hector, A., Jactel, H., Koricheva, J., Loreau, M., Mereu, S., Messier, C., Muys, B., 
Nolet, P., Paquette, A., Parker, J., Perring, M., Ponette, Q., Potvin, C., Reich, P., Smith, A., Weih, M., Scherer-Lorenzen, M., 2016. Contributions of a global network of tree diversity experiments to sustainable forest plantations. Ambio $45,29-41$. doi:10.1007/s13280-015-0685-1

Verstraeten, G., Vancampenhout, K., Desie, E., De Schrijver, A., Hlava, J., Schelfhout, S., Verheyen, K., Muys, B., 2018. Tree species effects are amplified by clay content in acidic soils. Soil Biology and Biochemistry 121, 43-49. doi:10.1016/j.soilbio.2018.02.021

Vesterdal, L., Clarke, N., Sigurdsson, B.D., Gundersen, P., 2013. Do tree species influence soil carbon stocks in temperate and boreal forests? Forest Ecology and Management 309, 4-18. doi:10.1016/j.foreco.2013.01.017

Vesterdal, L., Schmidt, I.K., Callesen, I., Nilsson, L.O., Gundersen, P., 2008. Carbon and nitrogen in forest floor and mineral soil under six common European tree species. Forest Ecology and Management 255, 35-48. doi:10.1016/J.FORECO.2007.08.015

Vitousek, P.M., Chadwick, O.A., 2013. Pedogenic Thresholds and Soil Process Domains in Basalt-Derived Soils. Ecosystems 16, 1379-1395. doi:10.1007/s10021-013-9690-z

Vogel, H.-J., Bartke, S., Daedlow, K., Helming, K., Kögel-Knabner, I., Lang, B., Rabot, E., Russell, D., Stößel, B., Weller, U., Wiesmeier, M., Wollschläger, U., 2018. A systemic approach for modeling soil functions 4, 83-92. doi:10.5194/soil-4-832018

Wang, H., Liu, S.-R., Wang, J.-X., Shi, Z.-M., Xu, J., Hong, P.-Z., Yu, H.-L., Chen, L., Lu, L.-H., Cai, D.-X., 2016. Differential effects of conifer and broadleaf litter inputs on soil organic carbon chemical composition through altered soil microbial community composition, An-Gang Ming. Scientific Reports 6. doi:10.1038/srep27097

Zanella, A., Jabiol, B., Ponge, J.F., Sartori, G., De Waal, R., Van Delft, B., Graefe, U., Cools, N., Katzensteiner, K., Hager, H., Englisch, M., Brethes, A., Broll, G., Gobat, J.M., Brun, J.J., Milbert, G., Kolb, E., Wolf, U., Frizzera, L., Galvan, P., Koll, R., Baritz, R., Kemmers, R., Vacca, A., Serra, G., Banas, D., Garlato, A., Chersich, S., Klimo, E., Langohr, R., 2014. European Humus Forms Reference Base.

Zimmermann, M., Leifeld, J., Schmidt, M.W.I., Smith, P., Fuhrer, J., 2007. Measured soil organic matter fractions can be related to pools in the RothC model. European Journal of Soil Science 58, 658-667. doi:10.1111/j.1365-2389.2006.00855.x 


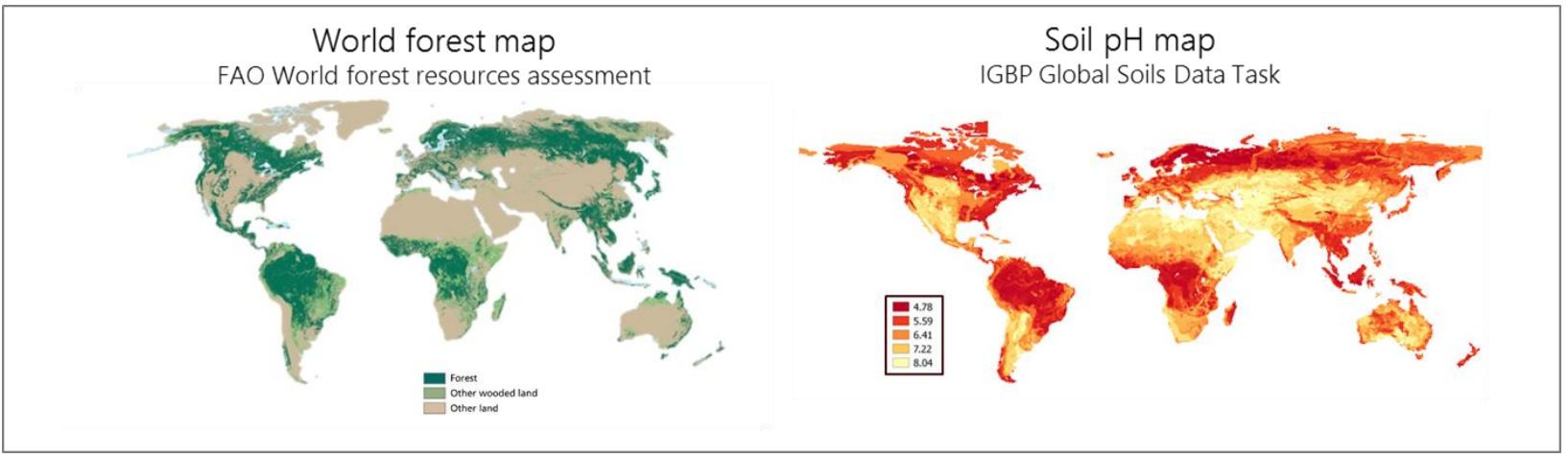

595

596

597

598

599

Table. S2. Overview of dataset and carbon subset. Plots are ranked based on clay content.

\begin{tabular}{|c|c|c|c|c|}
\hline Twin-plot & Geology & Clay content (\%) & $\begin{array}{l}\text { Soil process domain } \\
\text { (deciduous plot) }\end{array}$ & Carbon dataset \\
\hline 22 & Luxembourg & 4.70046 & Aluminium & \\
\hline 36 & Luxembourg & 4.8264 & Aluminium & $x$ \\
\hline 8 & Luxembourg & 5.49994 & Aluminium & $x$ \\
\hline 12 & Luxembourg & 6.31643 & Exchange & $x$ \\
\hline 15 & Luxembourg & 6.47122 & Aluminium & \\
\hline 16 & Luxembourg & 6.83493 & Aluminium & \\
\hline 13 & Luxembourg & 7.46528 & Aluminium & \\
\hline 11 & Luxembourg & 7.74801 & Aluminium & $x$ \\
\hline 2 & Luxembourg & 8.39291 & Aluminium & $x$ \\
\hline 21 & Luxembourg & 9.273 & Aluminium & $x$ \\
\hline 17 & Arlon & 10.39184 & Exchange & $x$ \\
\hline 29 & Arlon & 10.4122 & Exchange & \\
\hline 19 & Arlon & 10.52302 & Aluminium & \\
\hline 9 & Arlon & 10.55077 & Aluminium & \\
\hline 27 & Arlon & 11.11994 & Exchange & $x$ \\
\hline 26 & Luxembourg & 11.55765 & Aluminium & $x$ \\
\hline 5 & Arlon & 11.99477 & Exchange & \\
\hline 25 & Arlon & 12.21832 & Exchange & $x$ \\
\hline 30 & Arlon & 12.26116 & Exchange & \\
\hline 1 & Arlon & 12.3779 & Exchange & \\
\hline
\end{tabular}

Fig. S1. Left: world forest map adapted from (FAO, 2015). Right: World acidity map (soil pH) adapted from (IGBP-DIS, 1998). 


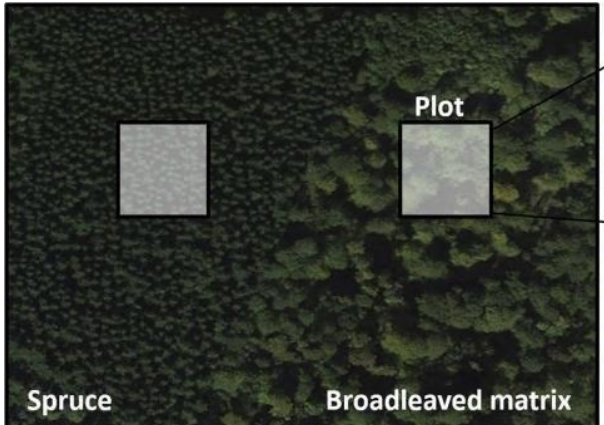

Sampling:

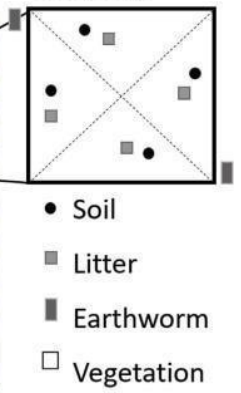

Fig. S3. Scheme of twin-plot set-up in the Gaume forest. (Verstraeten et al., 2018)

604
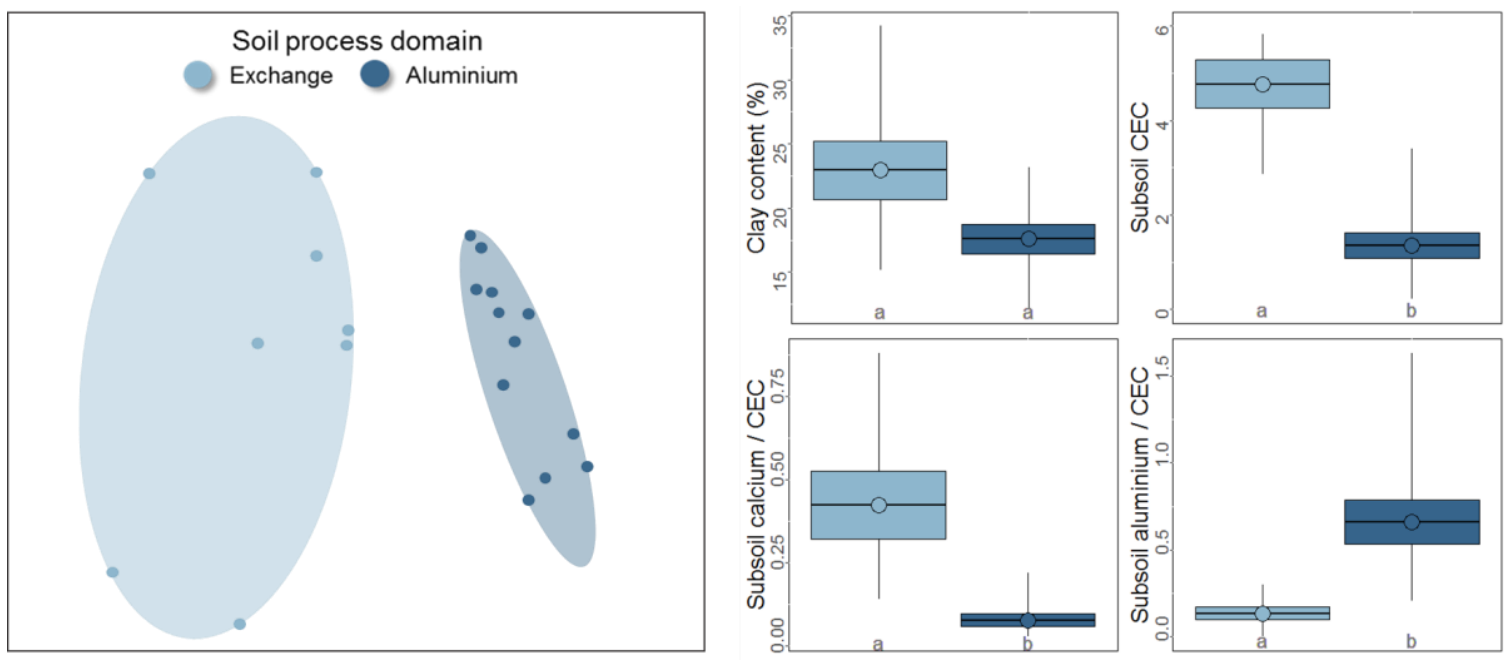

Fig. S4. Left: K-mean cluster analysis of deciduous plots based on variables texture, subsoil CEC, subsoil

607 exchangeable aluminium and exchangeable calcium. The two resulting components explain $79.16 \%$ of the point variability. Right: boxplots of above mentioned variables for deciduous plots located in the exchange domain and for deciduous plots located in the Al domain. Results of a post hoc multiple comparison test

$610(\alpha<0.05)$ are indicated below the boxes: different letters indicate a significant difference between the mean of two boxes. 


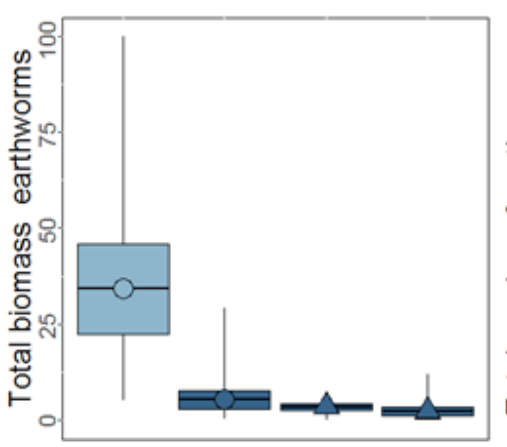

612

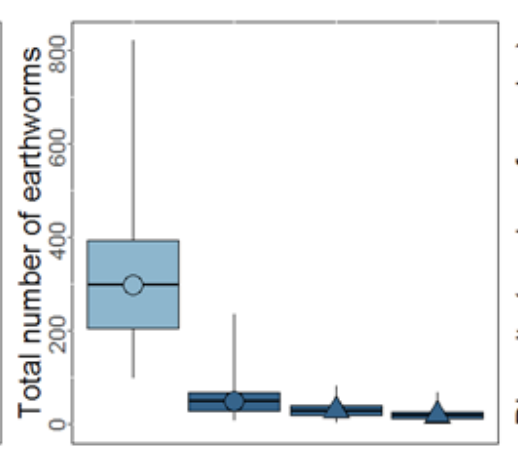

Forest type

Deciduous $\triangle$ Spruce

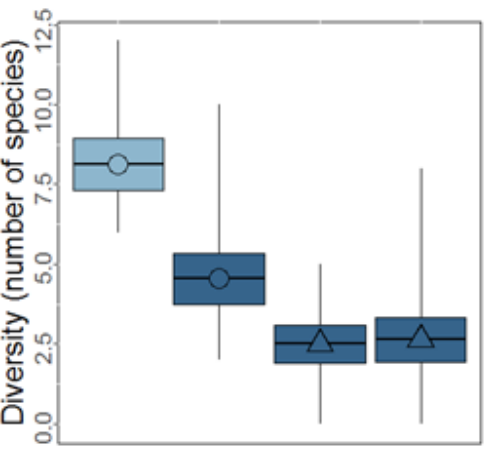

Soil process domain

Exchange Aluminium

613 Fig. S5. Values (range, standard error and mean) before and after conversion and per initial soil process

614 domain for total earthworm biomass $\left(\mathrm{g} / \mathrm{m}^{2}\right)$ (left), total number of earthworms (middle) and total number

615 of earthworm species (right). A distinction is made between deciduous plots initially in the exchange 616 domain (light blue) or in the Al domain (dark blue). 

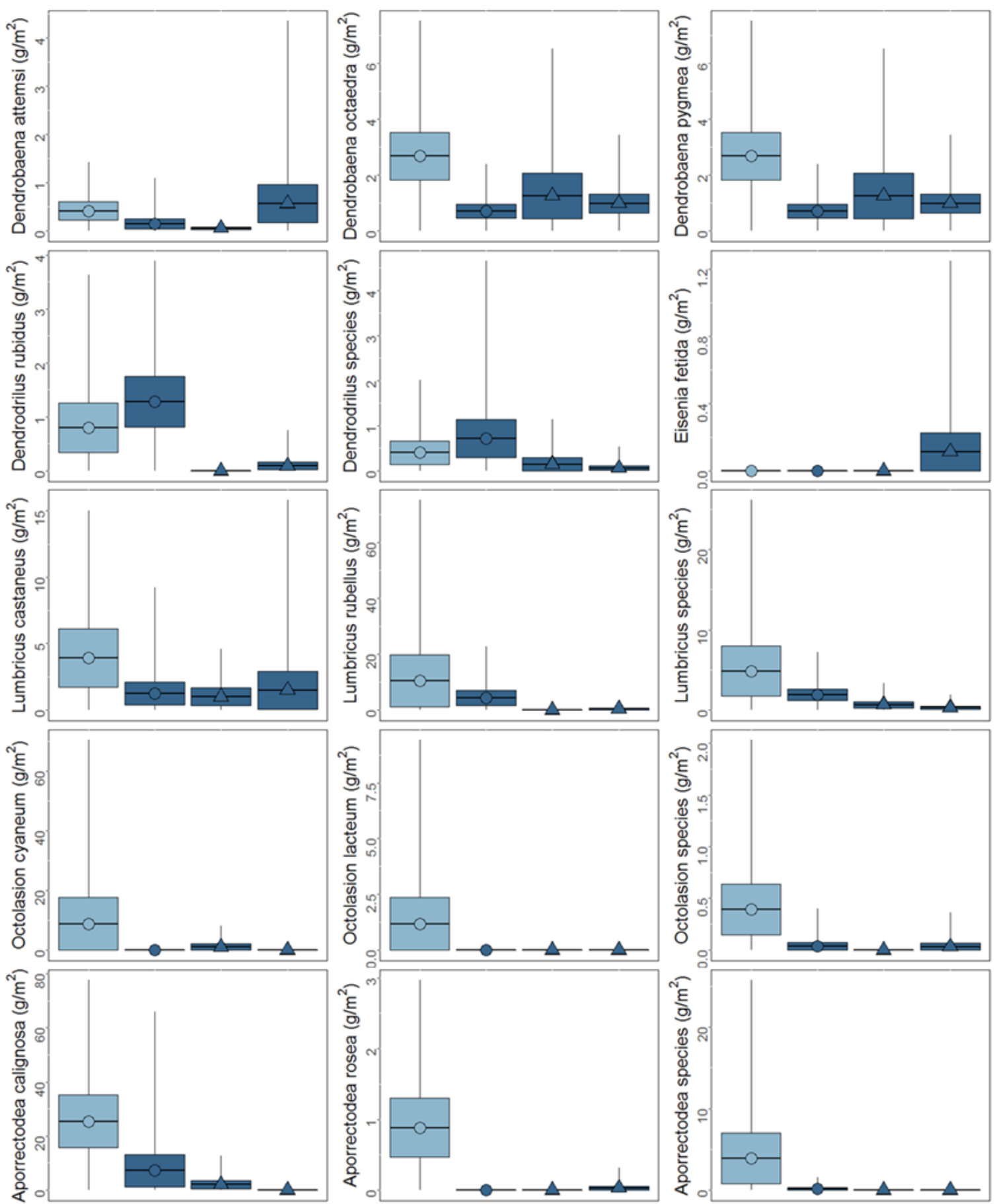

Forest type

Deciduous $\triangle$ Spruce
Soil process domain

Exchange Aluminium

618 Fig. S6. Biomass $\left(\mathrm{g} / \mathrm{m}^{2}\right)$ values (range, standard error and mean) before and after conversion and per initial soil process domain for different earthworm species. A distinction is made between deciduous plots initially in the exchange domain (light blue) or in the Al domain (dark blue). 